\title{
The Myth of Americanization or the Divided Heart: U.S. Immigration in Literature and Historical Data, 1890-2008
}

John F. Moe

\section{(2) OpenEdition Journals}

Electronic version

URL: https://journals.openedition.org/ejas/8935

DOI: 10.4000/ejas.8935

ISSN: 1991-9336

Publisher

European Association for American Studies

Electronic reference

John F. Moe, "The Myth of Americanization or the Divided Heart: U.S. Immigration in Literature and Historical Data, 1890-2008", European journal of American studies [Online], 6-2 | 2011, document 3, Online since 04 April 2011, connection on 08 July 2021. URL: http://journals.openedition.org/ejas/ 8935 ; DOI: https://doi.org/10.4000/ejas.8935

This text was automatically generated on 8 July 2021 .

Creative Commons License 


\title{
The Myth of Americanization or the Divided Heart: U.S. Immigration in Literature and Historical Data, 1890-2008
}

\author{
John F. Moe
}

The concept of "Americanization" is imbued with, and inextricably bound to, the American imaginary. This article examines the results of the United States Census data and, at the same time, reflects on literary and folkloric references to the idea of "Americanization." Together, the data and the narrative sources illustrate the extent of the impact of immigration, over time, on the American imaginary. Beginning with the myth of "Christobal Colon" [Christopher Columbus], the phenomenon of immigration to the North American continent results in the enigma of identity in a pluralistic society. This article profiles the trends of population change in the United States. At the same time, I examine the literary humanistic evidence of social identity in the "New World," the world of the "American Imaginary." The "Old World" is not the one traditionally privileged by American Studies scholars, but rather, the "Old World" today is not only Europe, but it is also Asia and Africa as well as Latin America. Farsighted Nineteenth Century poet Walt Whitman was perhaps the most prescient on this score when he envisioned emigrants from all continents coming to America. In "Leaves of Grass VI" Whitman hailed the world in his poem "Salut au Monde" by addressing in the opening line "You, Whoever You Are." Whitman's exuberance over people arriving from across the world echoed the attitude of many Americans during the middle of the Nineteenth Century, however this enthusiasm had faded by the end of the Twentieth Century. The problems of immigration are today both on the side of the incoming emigrant as well as the host society. Contemporary Twenty-First Century EthiopianAmerican writer Dinaw Mengestu notes in his first novel, The Beautiful Things that Heaven Bears, the conflicting aims and dilemmas of the new immigration. His protagonist thinks to himself that he really belongs to two countries, that he possesses two cultural identities. Herein lies the central difficulty of the myth and reality of 
"Americanization." At the outset, the problem of "Americanization" is best described by the profile of the U.S. Census numbers coupled with the literary expressions of immigrant individuals themselves. The central concern of this article is to provide a framework within which to examine the emigrant life within the scope of both the historical data and the literary evidence of the world of the immigrant.

I am an American who has been fortunate to live outside the United States for three years in order to teach American Studies as a Fulbright Professor at universities in Norway, Finland, and Estonia. I have lived and done fieldwork in Turkey as well. I am a product of a lifetime of academic work studying American culture. When I was an undergraduate in college, American Studies was a relatively new formal academic field. When I arrived at graduate school, I studied with professors who had earlier helped to define the nascent American Studies discipline. This generation of professors was the first generation of graduate students in the program of American Civilization Studies at Harvard University during the immediate post-World War II period in the late 1940s. As a graduate student, I studied with the academic faculty who changed the scope and landscape of American culture studies by expanding the interdisciplinary nature of American Studies from the traditional history/literature paradigm and integrating the new discipline of folklore into the conversation. ${ }^{2}$ I studied with Professor Richard M. Dorson, a student of Professor Perry Miller in the American Civilization at Harvard. Dorson, at that time, was developing the field of American folklore when people said there was no American folklore. During all of my student time, I earned university degrees in four different disciplines, all in American areas of literature, history, folklore, and American Studies.

Now, as a result of my student experience and later teaching American Studies at the university, I continue to be intellectually intrigued with, as well as emotionally connected to, the constantly changing milieu of American society. American society presents a myriad of different faces to the rest of the world and, of course, not all of these faces are as favorable as they might have been to some in the immediate postWorld War II years. Today, we are confronted with a bifurcated image of American society. One image is that of the sole dominant military power remaining, following the Cold War, and, the other is that of a nation that is the new home to an arriving generation of emigrants to American society. The "New Immigration" to American society during the late-Twentieth Century and the early years of the Twenty-First Century rivals in numbers and significance the historically important "New Immigration" at the turn of the last century. By way of introduction, it is important to note that the political problems of integration and social assimilation that face the United States are not unique to that country, but rather these problems are becoming social factors throughout Europe and parts of Latin America and Asia. The United States may present some distinctive factors, yet the problems related to international migration are felt throughout many societies.

Since "the great migration" of the end of the nineteenth century, the United States has been beset with an ongoing internal debate concerning what it means to be an "American," (with an equally complex debate ongoing in Canada) and the discussion surrounding this debate has oscillated with respect to the demands of the time period. Popular and high-brow literature before 1900, including the novels The Europeans (1878) by Henry James and Ragged Lady (1899) by William Dean Howells, demonstrate the clear obsession with the notion of what it meant to be an American. Both novels focus on the 
development of an American quality of character, born of a democratic upbringing, in contrast to the character of Europeans arriving out of a privileged class-ridden society. Stephen Crane (1871-1900) addressed exactly this point in his description of the plight of the emigrant in his classic naturalistic story, "The Blue Hotel" (1898). The story revolves around the dominance of ethnic and regional stereotyping in the Frontier West. With a central character identified only as the "Swede," who was Crane's emigrant trope for the newly arrived immigrant at the end of the Nineteenth Century, the Swede was doomed to failure in the New World as a result of his lack of understanding of the American context. Crane described the Swede in vulnerable terms: he was, Crane penned, "a shaky and quick-eyed Swede, with a great, shining, cheap valise..." ${ }^{3}$ The "cheap valise" was a signal marker for the current state of immigration and the Swede was fated because of his lack of language and cultural understanding of American social values. Early, the American populace assumed the acquisition of an American English language and an understanding of fundamental social expectations that would lead to a becoming the "ideal American," one who would be a substantially different person from the European counterpart. Within the personal accounts and memoirs that emanated from each European culture one can read the hopes and desires that emigration to America would result in citizenship in the new country. In each European country the phenomenon was called something different. In Norway and throughout the Scandinavian/Nordic countries, it was referred to as "American fever." At the end of the Nineteenth Century and the beginning of the Twentieth Century, this "American fever" swept through many primarily European localities where, for example, in some northern Norwegian communities, nearly half of the population left for the New World seeking opportunity that they perceived waited for people anxious to take up the reins of toil and effort to build a new life. Literary and historical examples exist for each European national group. Archetypal examples for this body of literature include Carl Wittke's classic history of German immigration to American, We Who Built America, published in 1939, and The Italian Emigration of Our Times, by Robert F. Foerster, published by Harvard University Press in 1924.

My argument, at the outset, is that "Americanization" is driven not only by the facts and numbers surrounding immigration, but also that the question itself of Americanization implies the position of national policy toward immigration, toward the sense of "otherness" that emigrants experience. Further, I suggest that the process of Americanization involves, necessarily, the existing prejudice between ethnic groups that continues on into subsequent generations. Before beginning this argument, it must be noted that the United States has been historically, and in folklore, known, as John F. Kennedy portrayed it to the rest of the world, as a "Nation of Immigrants." This terminology of historic characterization has been the title of literally thousands of items in America from textbooks to films to museum exhibits. The idea and the folklore of the "Nation of Immigrants" have dominated the perception of what the American dream can offer and, indeed, what immigrants expect from the host culture.

In addition to Census data, I also discuss the current dilemma concerning immigration throughout the United States by using examples of diversity within the American population. Immigration reached a peak of 8.8 million immigrants from 1901-1910. Steven A. Camarota notes that this number was only recently surpassed when, during the period of 1991-2000, 9.1 million legal immigrants entered the United States. ${ }^{4}$ During the intervening century, immigration averaged around four million per year, leaving the two high immigration periods as interesting "bookends" for the study of entrance 
into an American society that has changed so significantly from the end of one century to the end of the next. The historical significance of these numbers cannot be overstated. Steven A. Camarota points out that "[o]ne of the interesting features of current immigration is that such a large share of immigrants stay permanently." Citing a study from the Population Reference Bureau in Washington, D.C., Camarota notes that because so many of the early Twentieth Century immigrants chose to return to their homelands, the overall impact on the population was not as great. ${ }^{5}$ For example, approximately $25 \%$ of Norwegians returned to Norway after a period of time. This pattern continued in Norway until the 1980s, when Norwegians returned with their big American cars, commonly called "boats" and the former emigrants initiated days called "American Days" when they drove their American cars and only spoke English. ${ }^{6}$

Another tool for examining the "myth of Americanization" is the New Immigrant Survey [NIS], a multi-cohort prospective-retrospective panel study of new legal immigrants to the United States. The NIS is supported by a wide array of national government agencies and foundations, including the National Institutes of Health, National Institute on Aging, the National Science Foundation, and U.S. Immigration and Naturalization Service. The survey was first piloted in 1996, the first full cohort sampled immigrants in 2003, and the next round of interviews was conducted in 2008. Interviews are conducted in nineteen languages: English, Spanish, Chinese, Korean, Polish, Russian, Tagalog, Vietnamese, Arabic, Croatian, Farsi, French, Gujarati, Hindi, Serbian, Ukrainian, Urdu, Amharic, and Haitian Creole. The census data and the data from the NIS are presented here in an effort to examine the rough outline of the numbers of immigration to the United States and to begin my discussion of a potential "dual or double consciousness" in American society.

The sheer numbers of current emigrants into the United States make the topic of "Americanization" compelling. In fact, between January 2000 and March 2005, 7.9 million new immigrants settled in the United States, the largest number of immigrants to come into the country during any five-year period in American history. Recent data from the Center for Immigration Studies indicate that the number of immigrants living in the U.S increased between 2005 and 2007 to a total of 37.3 million (see Figure 1). ${ }^{7}$ 


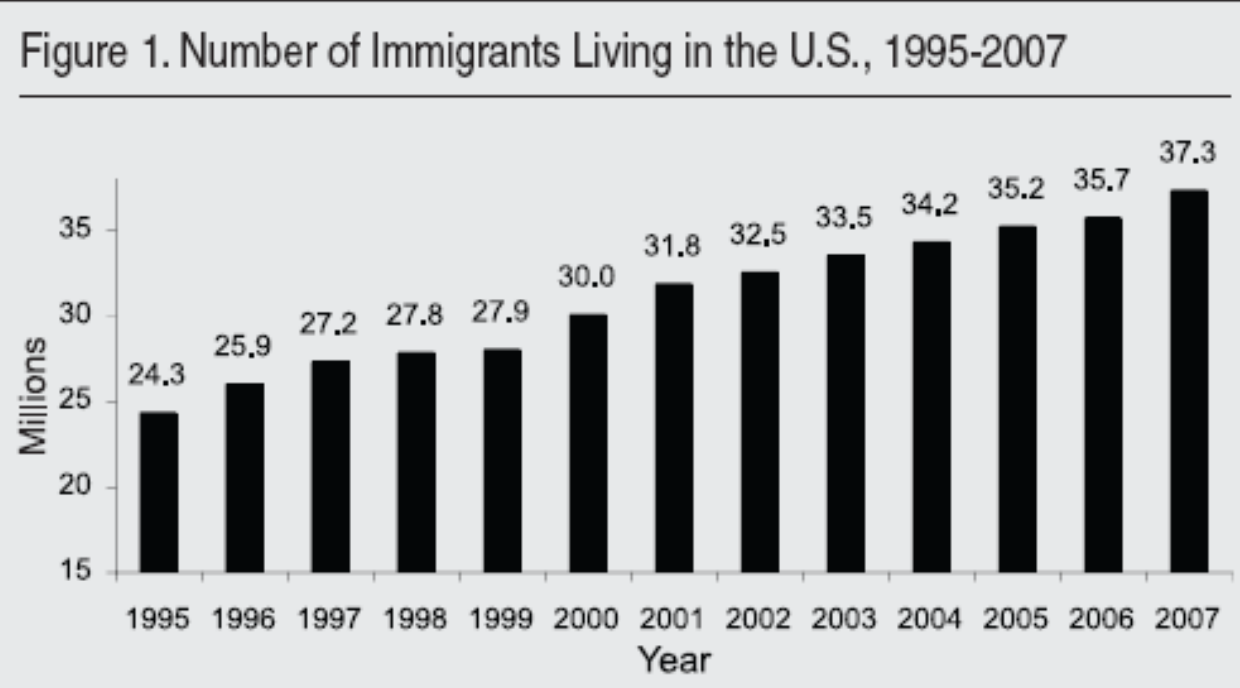

Source: Center for Immigration Studies analysis of March 1995 through 2007 Current Population Surveys (CPS). The CPS does not include persons in group quarters, such as prisons and nursing homes. Figures for 1995 to 1999 have been re-weighted to reflect the larger number of immigrants revealed in the 2000 Census.

The Center for Immigration Studies reports that the 37.9 million immigrants, both legal and illegal, living in the United States in March 2007 was the highest number recorded to date (see Figure 2).

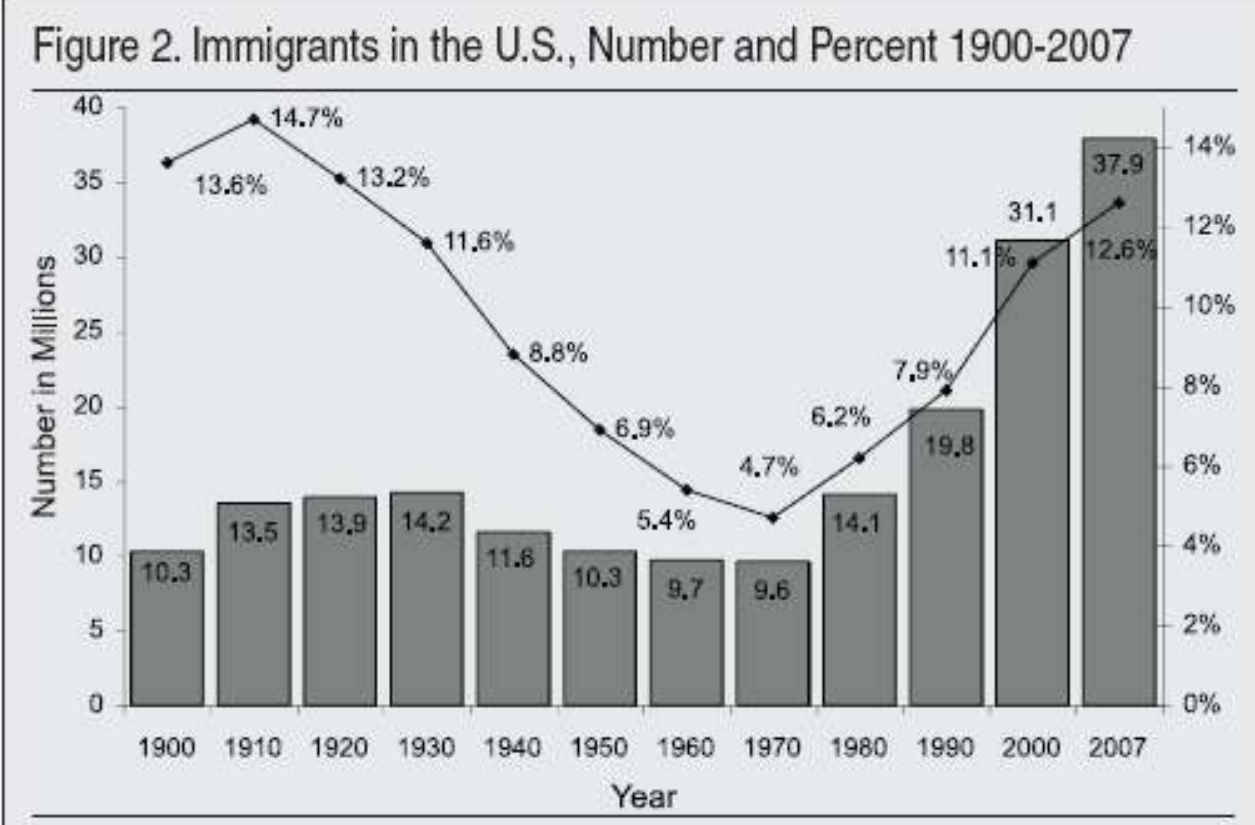

Soutce: Decennial Census for 1900 to 2000. For 2007 we used the March Current Population Survey, which does not included those in group quarters. The 600,000 immigrants in group quarters have been added to the 2007 CPS to make it comparable with the historic censuses.

The current number of immigrants living in the country is two and a half times the 13.5 million during the peak of the last great immigration wave in $1910 . .^{8}$ of the total number of immigrants coming to live in the United States today, 3.7 million, nearly half of those who came after 2000, are estimated to be illegal aliens. Among all issues that pertain to the current immigration concerns, the impact of a disproportion of illegal immigrants poses a series of impending problems that will have important and perhaps 
dramatic consequences in the future. However, the dramatic increase of emigrants living in the United States from the former peak year of 1910 to the current level of emigrant population in 2005 is the focus for the following discussion.

I am also the product of relatively recent Twentieth Century immigrants. Both of my father's parents were immigrants while on my mother's side her father was an immigrant and her mother was the product of two immigrants. Three of four of my grandparents were immigrants. During the time that I was growing up in Iowa, it was not at all an unusual circumstance to have immigrant grandparents, or, at least greatgrandparents. Iowa was a place where many immigrants and the children of immigrants were able to find the "American Dream." Soon after the Second World War, the Lutheran World Federation and Lutheran congregations in America enabled scores of people from the Baltic countries to settle in the Midwest of the United States. ${ }^{9}$ Many, if not most, of these people fell into the category of "Displaced Persons" and were at the time living in the famous "DP Camps" throughout Eastern Europe. Following the Displaced Persons Acts of 1948 and 1950, aimed at relaxing immigrant quotas to help resettle war refugees, the United States became a destination for many Estonians in German displaced persons camps. I went to school with their children, played sports with them in college, and became life-long friends-all without a thought about their origins..$^{10}$ Though we understood how these people arrived, their Estonian and Latvian names were not so different than the existing mosaic of names we all carried. The simple fact was that we all were Iowans, living in the State of Iowa, Americans I guess too, and we all spoke with one language. Our loyalties were probably more to each other. It was certainly not uncommon at all to hear parents speak with an accent and grandparents talking in another language we did not understand, but our generation was speaking with an American English accent. Many of our parents would not teach us their former "home" language because, as my father said, "I don't want you to have a Norwegian accent; we are Americans now."

We learned to speak without an accent probably without reflection, without dwelling on whatever language facility was lost in the transfer of generation. I remember asking my Danish maternal grandfather, my morfar, if he ever wanted to return to Denmark. He said that he went back twice after his emigration, once to visit his father who was old and failing and once more to visit his last remaining sister. My grandfather was the next to the last of thirteen children. He had no land to inherit and no prospects of much of a future in Denmark, so he came to American in 1913 along with a host of other young Danish lads looking for a new place to call home. He told me that when he came back to Iowa the last time he brought a Danish flag, but he carried an American passport. The transition to America was now complete; the last visit had been made. He had a strong Danish accent and always read to me aloud the Danish Hall newspaper. "Hör du det, [Listen], he would say, "Hör du det," and then he would read to me a story in Danish. ${ }^{11}$ My father and my Danish grandfather would talk with each other in Norwegian and Danish. Another man who worked for my grandfather, nick-named Swede, also joined in the boisterous talk among the three Scandinavians-in Swedish. Their play in language was my first experience with seeing and judging the rivalry among the Norwegians, Danes, and Swedes.

It was a lot to take in, but I never thought of it as such. The fact was that while all the students in school had different kinds of names, they all came from some part of Europe and, hence, what we thought of as differences were only as deep as the variation in the whiteness of skin color in faces from northern or southern Europe. 
Probably the most salient difference for us at that time was religion. Some people were Catholic and most were Protestant, but this was only evident on Sunday and even there the biggest tension was between the different branches of Protestantism, whether one was Lutheran or Methodist, and so on. Multiculturalism, as we call it today, was a fact of life in the 1960s, as normal to everyday existence as going to school. Perhaps it was this circumstance that inspired me to study American civilization when I arrived at college. I wanted to understand what was unique about America and what made these emigrants comfortable with their assimilation into American society. I was part of the generation that profited by the emigrant success in achieving the American Dream. Actually, it is not so different in Iowa today, but the points of origin are more likely to be India or Pakistan or Bosnia or Somalia. The question that looms today is whether the immigration patterns in the first decade of the Twenty-First Century are fundamentally different that those of fifty years ago and whether or not, what are perceived to be the current tensions are simply part of the grand continuum of emigration and assimilation in United States society. A recent story by Will Weaver entitled "Gravestone Made of Wheat" contains an example of the tensions that existed shortly after the First World War between European immigrants. Weaver's short story tells about a German woman who, after living in Norway, came to Minnesota to marry a Norwegian farmer and how the couple faced the prejudice that existed between different northern European nationalities. ${ }^{12}$ Is the change in the composition of American society, specifically the society in the United States, a quantitative change in the rough numbers and percentages of emigration, or is it a qualitative change deriving from fundamentally different populations coming together? Needless to say, this is a question that is also occurring throughout European society as well as American society.

I think of the emigrant circumstance each time I register my grades for the term at my university. I am always struck by the degree to which the names of the students in each class roster embody American multi-ethnicity and multiculturalism. Keeping in mind that the context of these classes is not New York or some similarly urbanized East or West coast place, but rather in Ohio in the middle of the Midwest, the names of the varied students become even more instructive. Each individual name-Persian, Jewish, Irish, English, German, Italian, Indian, Chinese, Hispanic-reveals a national or ethnic background and the group of names illustrate just how varied the current American social web has become. Contemporary American society is not defined only by white and black as so many people might believe-or even by white, black, brown, and yellow; but rather, the point is that the metaphor of American society today requires deeper and more subtle differentiation, one that allows for and accommodates ethnic complexity. Deriving a new metaphor compels us to find a different definition of social transformation.

During each succeeding generation of Americans, people who consider the meaning of "Americanization" struggle with the question of the relationship between the individual and society. At each stage of intellectual questioning, students of American history are encouraged to consider again the timeless question posed in the Eighteenth Century by the incomparable Frenchman, Hector St. John de Crevecoeur. In his Letters from an American Farmer, "What then is the American, This New Man?" Crevecoeur's fascinating and complex question has echoed throughout American Studies and perhaps most students of the discipline framed at least one paper in their student career around this simple, provocative, and demanding query. Philip Gleason noted in 
his essay on "American Identity and Americanization" in the Harvard Encyclopedia of American Ethnic Groups (1980) ${ }^{13}$ that Crevecoeur's question "has probably been quoted more than any other in the history of immigration." More recently, Ali Behdad, a professor of English and Comparative Studies at the University of California at Los Angeles, offers a penetrating cultural analysis of Crevecoeur in his 2005 book, A Forgetful Nation. Behdad notes that Crevecoeur has been cited as America's first "moral geography" and makes a cogent argument that the Letters from an American Farmer, as a text, offers a quintessential articulation of the emerging American identity, replete with all its faults of exclusivity, particularly the treatment of the American Indian.

Nathan Glazer, the indomitable Professor of Education and Sociology at Harvard University, raises Crevecoeur's question and answers by saying the question is not really asking what it takes to be an American, rather the question ponders a different query. Glazer notes that subtext of the question "is really, can we continue to be one American people when we are from so many diverse sources? If so, what kind of people does that make us?"14 Finally, the question, "what kind of people does that make us?" is perhaps the most fundamental question of American social and political culture today. ${ }^{15}$ The implications of the question range from building a wall between the United States and Mexico, to fighting wars in other countries, to who will be entitled to entitlements in the social welfare system of the United States. Glazer offers a series of penetrating questions and answers to the notion of Crevecoeur's fundamental query. Indeed, the discussion that Glazer offers in response to the question "what is an American" is at the heart of the overall concern of immigration and assimilation, to wit, what is implied by the "myth of Americanization." Perhaps it is more appropriate to address the concern as the "matrix of Americanization" because it is at the point of confluence, the matrix that we can begin to make, to devise, an answer adequate to the meaning of the riddle of what "Americanization" actually means. I cite one example. The electrician who comes to my house is named Asad. I first noticed his name embroidered on his work shirt just above the pocket. His father is of Irish descent, so he has an Irish last name. This fact comes out when I talk to him about the fact that his son wants to go to the university where I work. I discover that his last name is very Irish. His son also has a strong Irish first name, Brendan, making his son's whole name very Irish. When I commented on this, Asad said to me, "It gets better; my wife is bi-racial. [meaning that his wife is half Caucasian and half African American]" Therefore, in the matrix of American multi-ethnicity, this $3^{\text {rd }}$ generation American with the Irish full name, is part Middle-Eastern and part bi-racial African American. The circumstance is not at all unusual in American society today.

The delicate arras of American society, the tapestry woven into a cloth, the fabric of American ethnicity, race, religion, and culture, is the material culture analogue to illustrate what the concept and idea of "Americanization" might mean to the different groups within the society. The quandary in the answer to Glazer's question, "What kind of people does that make us?", is embedded in the balance between the vested interests that divide community and those interests that will provide unity and can unify a community. Historically, the interests that unify a community are in rough proportion to the strength of the ruling class and majority. As communities change, the dominant host culture becomes more wary of the significance of change. This has been true throughout American history, but with the dramatic change in overall population numbers during the 2000's, the stakes of change have greatly changed. Peter A. Morrison, writing a Rand Corporation "Documented Briefing: A Demographic 
Perspective on Our Nation's Future," remarks that a "complex ethnic mosaic is materializing across the country." Morrison reports that the Census Bureau projections from the late 1990s which "show a population in which Hispanics will soon outnumber African Americans; and non-Hispanic white (Anglo) persons will become the minority by 2060 , comprising less than half of all Americans." 16 The demographic and cultural change in the United States is so fundamental that the concept of "Americanization" prevalent even a half century ago would now feel and appear alien to the current society wherein ethnic expression is customary.

Morrison alludes to a complex ethnic mosaic that is slowly beginning to define not only a different ethnic America but also a fundamentally different society in which intermarriage is rising and, according to the RAND survey, more Americans identify themselves as "multiracial." The recent novel by Karen Tei Yamashita, Tropic of Orange, illustrates this point. Yamashita, who is from California and attended the Iowa Writer's Workshop, describes a deeply ethnic California society interwoven with Mexican Americans, Japanese Americans, and African Americans along with white European Americans. ${ }^{17}$ She uses hypertext narratives in which characters, each from a different ethnic heritage, interact tangentially in their search to fulfill individual aspirations and to solve dilemmas posed by a complicated multiethnic society that encompasses both Mexico and the United States.

Let us look at a few relatively typical communities in order to understand the depth of proportionate change. Fresno, California, according to the 1990 Census, is one of the cities undergoing dramatic change. Hmong, peoples primarily from Laos, and other refugees constitute 9 percent of the population. Moreover, 14 percent of the adults in Fresno were not yet citizens and 12 percent of the children were non-citizens. In addition, over half, 55\%, of the Asian-language households were linguistically isolated. Lowell, Massachusetts, one of the long-time sites of the National Folk Festival over the past twenty years, is another example of an American city undergoing tremendous ethnic change. Cambodian and Laotian refugees comprise 8 percent of the population, $12 \%$ of the adults are not citizens, $11 \%$ of the children are not citizens, and $53 \%$ of the Asian-language households are linguistically isolated. Arlington, Virginia, a suburb of Washington D.C., is an example from another part of the country where the statistics indicate similar processes of rapid change. Hispanics comprise $13 \%$ of the population with embryonic communities of Vietnamese, Koreans, and Cambodians. In Arlington, $43 \%$ of the new immigrants arrived in the last five years. The alteration of the local urban landscape is a repeated feature throughout the United States. Minneapolis, Minnesota, has reported the largest number of both Hmong and Somali refugees, while Lansing, Michigan reportedly the second largest number of Hmong peoples. The pattern of relocation is witnessed throughout the Midwest. For example, Columbus, Ohio, has significant populations of both Somali and Arabic refugees from the respective wars in those geographic areas. In Columbus, the large ethnic Somali population numbers in the thousands, second only to Minneapolis, and has a cityfunded school and many businesses, such as grocery stores and restaurants, that cater to themselves as well as the rest of the community.

When I was a student of American history, we learned early about the Oscar Handlin's influential "Uprooted" thesis regarding the plight of European emigrants who sacrificed everything in order to find a new world in which they might achieve success. Handlin's The Uprooted was a seminal work that focused on the hardships endured by the emigrants in their journey and adjustment to the United States. ${ }^{18}$ Students 
considered immigration in the light of the "Melting Pot" and were taught that all immigrants would, within reason, meld into one composite "American" whole. Later, we learned that newer emigrants might not lose or relinquish all of their own identity and so we considered historian Carl Degler's formulation of the "Salad Bowl Thesis" as a more appropriate metaphor to describe how immigrants would retain their fundamental identity with a covering of unique American salad dressing that made us all Americans. The metaphor of a "salad bowl" was beginning to look more like a "unique" piece of fabric made up of many different pieces of cloth, all representing different ethnicities and origins. With each emigrant and emigrant family, the mosaic of the cloth changed slightly, much like the electrician Asad who came to my house. It was assumed during these early stages of American Studies that the key to understanding the interdisciplinary nature of the issue of Americanization was the concept of "uniqueness," that the United States was, in fact, a new and unique culture. This intellectual position held sway throughout the period from the late 1940s until the early 1980s, a period of nearly forty years. The idea of being "unique" was attractive and satisfactory to Americans who wanted the reaffirmation of their own younger society, but also to peoples in other parts of the Globe who desired some new answers for a world caught in the dilemmas of a deepening Cold War.

Particularly after World War II, the appeal of "American" as an idea yielded a resolution to the turmoil and confusion that dominated the world view of the 1940s. During this same time period, there was a vast undercurrent of discontent growing in American society with the position of American exceptionalism. Intellectuals, academics, and other concerned citizens examined the reasons for the maintenance of the folklore of American uniqueness. In all of these approaches to American social history and immigration, the emphasis was on the society and impact of the immigrant on the social fabric of the United States. In the 1960s this scholarly emphasis began to focus more upon the individual emigrant themselves, examining the impact of social change. During the late 1960s, the intellectual climate in the United States shifted in favor of individual concerns, foregrounding the individual American, to wit, we witnessed the rise of women's studies, African American studies, Native American studies, Asian American studies, Latino studies, and well as new studies of American immigration. Agency shifted from the society to the individual in immigration studies; from what was good for American society to what was the impact on the individual. However, all of this change concerned immigrants who still resembled, in their whiteness, those immigrants who came between 1890 and 1950. In recent years, the face of immigration has shifted again and the question of agency has become more difficult for those who attempt to answer Crevecoeur's question anew. The question requires a new metaphor in order to attempt to answer not only Crevecoeur but also answer Nathan Glazer when he asks how we can continue to be one American people when we come from such diverse sources.

As the question of individual agency has changed, so too has the metaphoric description. Because American society so clearly resembles a complicated fabric or textile made up of different colors and ethnicities, I am suggesting that the society of the United States be more likened to a rug, a floor covering or a wall tapestry, that incorporates the wide range of color and texture evident in the social fabric of America, the delicate arras that defines the day-to-day world of living in America. It was clear during the late 1960s that the time-honored configuration of the melting pot did not make much sense because one could observe that people were simply not becoming one 
homogeneous whole-or anything close to that central idea. Carl N. Degler wrote in his widely-used college history textbook published in 1970 that "the metaphor of the melting pot is unfortunate and misleading. A more accurate analogy would be a salad bowl," Degler wrote, "for, though the salad is an entity, the lettuce can still be distinguished from the chicory, the tomatoes from the cabbage." ${ }^{19}$ Degler's metaphor aptly attempted to demonstrate the subtle difference between Americans of different "stripe and color." The salad bowl thesis made a little more sense except for the fact that the emigrant was not a strictly bordered being either; little differences continue to exist in each person that made the whole harder to determine. Finally, neither metaphor aptly described what was happening to American society. In the shift from the impact on society to the impact on the individual, it became clear that a new metaphor was required to describe what was happening in American society at the beginning of the Twenty-First Century. Perhaps the new American society can be compared to a knotted rug or a traditional rag rug. The metaphor of the traditional rag rug, like the floor coverings found in nearly every society in the world, is adequate to describe an ethnic mosaic of people who must, perforce, live in one country. In every culture, people have old and worn out clothes that are put into active use in a new form, the form of the rag rug, sometimes called "trash rugs" in many societies. In every culture, people take old clothes and refashion them to produce new fabrics made of old components. In Finland, for example, the word räsymatto means a rug made of throwaway clothes. The genius of the rag rug is that it represents a complete reuse and revitalization of an old cultural item no longer in active use. The immediate suitability of the metaphor of the rag rug is that it is universal; perhaps all cultures that use cloth make some item from the used and worn pieces of cloth, as well as integrating new pieces of fabric. In the case of both the knotted rug and the rag rug, the entire rug depends upon each small piece in order for the rug to retain its original form as a rug, a rug that has wholeness (entirety) and integrity in and of itself. Finally, for our metaphor, the essence of the rug is both its usability and its potential for disruption (as in tearing or wearing out) and repair.

Let us then return to Nathan Glazer's admonition. He cautions us, as cultural critics and students of history, to pay attention to the subtext of the question of new American immigration. When Glazer asks, "Can we continue to be one American people when we are from so many diverse sources?" he is essentially asking about the central fabric, arras, of the society itself. If we use the metaphor of the rug in analyzing American society in the light of Glazer's comment, then we can see how the tapestry of the rug has become increasingly complicated from very similar fabrics to fabrics of different hues and textures. Glazer posits a profound question when he questions further whether "it is that there is something else that properly makes an American, and that is incorporation into an America that indeed includes the Declaration and the Constitution but is so much wider than that." ${ }^{20}$ It is perhaps precisely this point that Bernard Malamud, the Pulitzer Prize winning novelist, addresses in his classic novel The Assistant published in 1957. Malamud's protagonist is Frank Alpine, a Western man from California who comes to New York and finds ethnicity through working for a Jewish grocery store owner. Malamud's novel posits the irony of the man moving from West to east, unlike the classic move of Huck Finn to the Western territories, in order to strain the metaphor of "Americanization" itself. If we are to answer Glazer's question of whether we can become one people, then Malamud answers in the 
affirmative through Frank's circumcision and conversion. Malamud states in the last line in the book: "he became a Jew." 21

Through his question, Glazer searches for the common purpose inherent in the rich tapestry of the American rug. Along with many other historians, Glazer notes that the United States is a nation "that has been made up through most of its history almost entirely of one race, with a small minority of another bound up with the first from our origins, all observing the variants of one religion, speaking one language." ${ }^{22}$ While Glazer's notions are true, it is not as simple as it seems at first glance. The United States, and Canada for that matter, has largely a European, Judeo-Christian population; however, Glazer's assertions seem to imply more compatibility among the elements in this population than have actually existed throughout the history of immigration to North America. John Higham's Strangers in the Land: Patterns of American Nativism, 1860-1925, published in 1955, illustrates the depth to which nativist, anti-Catholic, and anti-radical sentiments affected the national polity at the end of the Nineteenth Century. ${ }^{23}$ As American culture largely assimilated the new immigrants from Southern and Eastern Europe with the older population from Western and Northern Europe, real and strong ethnic tensions emerged and continued between various nationalities and religions. A brief mention of some Twentieth Century American authors in addition to Malamud illustrates this point quite well. John Dos Passos' American Trilogy, Hemingway's Michigan stories, John Steinbeck's California tales, and James T. Farrell's Chicago Studs Lonigan adventures articulate the ethnic tensions of American society during the Twentieth Century. In each author's literary work, narratives are built around ethnic differences and tensions in order to create plot. Steinbeck's Tortilla Flats and Hemingway's "Indian Camp," for example, rely on the reader's casual knowledge of the American landscape in order to make the narrative story work and be successful. Finally, Milton Gordon's Assimilation in American Life, published in 1964, illustrates how, by the middle of the 1960s, an American population reached a type of stasis regarding ethnicity and assimilation. Gordon argued then that the overwhelming assimilation was in the area of civic assimilation, meaning simply that people living in the United States learned to obey certain fundamental laws. By the time of his research, Gordon also demonstrated that the use of a common language, English, was by and large agreed upon, a fact that by the beginning of the Twenty-First Century was not as accepted. Most importantly, however, Gordon argued that the United States did not enjoy assimilation in many critical and important ways, indicating that the fabric of society was not united in a way that might be considered assimilated. Citing embryonic problems for American society, he noted that in the areas of social, religious, and economic assimilation there were wide disparities within the American population. ${ }^{24}$ This is not to say that all Americas were the same. The myth of a cultural hegemonic "Americanization" pervaded what was recognized as a consensus-driven impulse in society. Americans of all "stripes" continued to find strength and solace in emigrant societies and ethnic communities after the war. For example, in 1948, Chicago Estonians organized the Chicago Estonian Society that co-existed with the Estonian Lutheran Church in the Andersonville area of Chicago. ${ }^{25}$ The Estonian emigrant community on the north side of Chicago formed in an area that already was known for its Nordic roots. Not far from the Estonian Lutheran Church was the Norwegian Lutheran Church and other organizations formed by Scandinavian immigrants. The Norge Ski club was founded in 1905 by Norwegians, most of whom lived in Chicago and traveled to an area outside the city called Fox River Grove where they would ski jump. 
Norwegian emigrants also organized other athletic clubs and one group in particular sponsored soccer games (futbol) including an annual game against clubs from Norway. Sometimes the Chicago club would travel to Norway for a futbol match. ${ }^{26}$ The north side of Chicago was known for its Scandinavian communities. Swedish churches and clubs existed there since the 1880s in the areas called "Andersonville" and North Park. In this sense, Chicago was typical of new American communities across the United States where after the 1880s multi-ethnicity became standard fare.

Ethnic identity and roots were strong in the New World of "Americanization." Odd S. Lovell, the preeminent Norwegian-American historian, wrote that by 1900, there were 41,551 Norwegian residents in Chicago, mostly on the near-north side, and by 1930 there were 55,948. Lovoll remarks that "These were the golden years of Chicago's 'Little Norway,' the third-largest Norwegian population in the world after Oslo and Bergen. ${ }^{27}$ Ethnic community pride is a consistent pattern of behavior in the United States. In Cleveland, Ohio, in the 1980's one often heard the popular folklore that the suburb of Parma "was the largest Polish city outside Poland," an assertion contested by other cities. Chicago, for example, makes a strong claim as "the largest city outside of Poland, with more than 180,000 Polish language speakers." ${ }^{28}$ Chicago hosts the "Taste of Polonia Festival" and, according to Program, a Polish language publication in Chicago, the city is the largest Polish community outside Poland with 800,000 people. ${ }^{29}$ In the Upper Peninsula of Michigan, Finnish emigrants came to work in the lumber camps and copper mines and today signs for Finnish food, in Finnish, abound. In addition, among new immigrant groups today, ethnic identification continues to merge with "Americanization." For example, next to a local theater in Columbus, Ohio an Indian restaurant advertises its food as "Where Bollywood meets Hollywood."

At the conclusion of the Second World War, Americans were flush and exuberant from the experience of international success. United as a people, in the same uniform as it were, Americans of the post-war period, in the popular imagination, eagerly attempted to redefine themselves in the light of newly found appreciation of their qualities as a people. It was a time of, as one book labeled it, the "Pax America," with all the attendant qualities of a different kind of empire than that of Rome or Great Britain, but an empire nonetheless. The new America was perceived as an empire of democracy, one of equality, of opportunity opened to all who would share in the dream and the success embodied in the idea of "America."

At the same time, the late 1940s saw the birth of the discipline of American Studies which, through the efforts of the United States government at home and abroad, grew in intellectual stature as well as breadth of undertaking. ${ }^{30}$ The work of academics such as Perry Miller, Samuel Eliot Morrison, Bernard De Voto, and Henry Steele Commager formed the cannon among those who wanted to understand the unique entity inherent in the conceptual term, "the American Spirit." In that earliest flush of intellectual excitement, detractors to the broad acceptance of American Studies as a new academic scholarly discipline were few. The academic argument for a unique American experience seemed incontrovertible. Not only was it grounded in the academic research of Perry Miller that brought us closer to our staunch founders, the Puritans, but also it followed the common sense of citizens who simply understood that life in the United States was somehow inherently different from life and culture particularly in Europe. Bigger cars, bigger agricultural yields, bigger universities, and popular movies that exuded the American "Western Spirit" combined to fulfill a dominant 
popular culture image of a United States culture that would continue to move forward with progress and confidence.

The American exposure to the rest of the world during the traumatic times of the "Big War" removed any lingering doubts that Americans were somehow more special. Soldiers were happy to be home and in the folklore of their experience they talked little of the harrowing experiences during the war. However, soldiers and their families and their communities were imbued with a confidence born of a popular film culture that continued to remind the American public that theirs was a virtuous and confidant endeavor. Bogart's "Casablanca" and scores of Hollywood films of the era reinforced the American position of an unyielding pattern of American success in fomenting democracy and subduing dictatorships. The impending success at the close of the war led Americans to position themselves as the harbingers of freedom and democracy, on the one hand, but on the other hand, Americans were also imbued with the idea that the United States was increasingly the world's safe haven. Because immigration was at low ebb (see graph in Figure 1), the question of whether the United States was a "safe haven" for new people did not arise. At the end of the war, the trope of freedom was unassailable. World War II stories were replete with accounts of European-American soldiers who fought for freedom in the countries of their own ancestors. Hyphenated Americans all -- Italian-Americans from New York, Irish-Americans from Chicago, and Finnish-Americans from Michigan reunited with their forebears. It was, at least in popular culture, a beautiful scene of harmony among people united by common effort.

The question of "the Myth of Americanization" loomed large after the experience of the Second World War. In many ways, the dominant popular theme of unity and the idea of Americanization ran contrary to the disturbing undercurrents in American society. Many ethnic populations suffered repression in American society including the continued legal segregation of a large African American population, incarceration of a portion of the Japanese-American population that struggled pitifully in detention camps during the war, and, of course, the continued prejudice against a myriad of other Americans who were either Jewish, or Italian, or Latino/a, and many other segments of the population. President Harry S. Truman recognized the hypocrisy of American treatment of minorities and, on July 26, 1848 issued "Executive Order 9981" which finally gave legal authority to the integration of the U.S. armed forces with the words "equality of treatment and opportunity for all persons in the armed forces without regard to race, color, religion or national origin." ${ }_{31}$ The former First Lady Eleanor Roosevelt drew attention to the plight of urban African American youth by actively supported the creation of programs for black children to attend camps and schools. ${ }^{32}$ The Servicemen's Readjustment Act of 1944 (called the G.I. Bill) offered financial assistance to veterans who wanted to buy a home or attend college. Universities and colleges provided temporary housing for the families of veterans, erecting prefabricated buildings and aluminum Quonset huts for classroom use by returning G.I.s. After the war, African American soldiers and their families believed that they were returning to a new United States only to find that the walls against integration were as great as ever. Many white people and institutions resisted the post war legal and social changes. Banks would not loan money for houses in certain neighborhoods, and the $\mathrm{Ku}$ Klux Klan once again raised its ugly head against Black inclusion in mainstream society.

Many creative writers began to address topics of social and economic inequality during the post-World War II period in the late 1940s. Some directly addressed lingering 
prejudice carried by whites from the war, where black servicemen were treated as lesser soldiers and used primarily as laborers. Minnesota novelist Sinclair Lewis, who had examined American Midwestern society for over two decades, having published his ground-breaking novel Babbitt in 1922, began to take a new and fresh look at the fabric of the Midwest culture. ${ }^{33}$ In two novels published in the forties, Lewis investigated the two dominant social themes that emerged in the United States after the war: first, the pressing problem of black-white relations and, second, the growing sense of multiethnicity in American social identity. Lewis dealt with the idea of biracialism and "passing" in his novel Kingsblood Royal, published in 1947, in which a white World War hero discovers that he is of "mixed" blood, descended from African American and white European-American ancestors. The protagonist, who had had always been considered "white," decides to explore his true identity rather than to quietly "pass" for white. Sinclair Lewis begins to explore rhetorically just how deeply racial prejudice runs in the American psyche. When Lewis presents the reader with the carefully drawn narrative in which the protagonist's wife rejects him for his "taint" of black blood, Lewis shifts the reader's attention to an exposé of racism and to the typicality of African American middle-class neighborhoods. Sinclair Lewis's narrative in Kingsblood Royal is remarkably prescient for the immediate post-war period and continues to be provocative even in the beginning of the Twenty-First Century.

Two years earlier, in 1945, Sinclair Lewis published his novel Cass Timberlane, in which he examines the more subtle concept of intermarriage among a number of European and American Indian populations, what he terms in the novel, "mongrel blood," meaning of course, the vast interbreeding of different types of ethnic backgrounds. Cass Timberlane, the protagonist of the novel by the same name, suffers a divorce in part because his wife could not abide "the mongrel blood of the furniture-dealing Timberlanes." With regard to the ethnic composition of his generation, Cass estimated that on his father's side, "he was three-eighths British stock, one-sixteenth French Canadian, and one-sixteenth Sioux Indian." Even today, it is not at all unusual for someone from the Midwestern states to claim some American Indian blood. On his mother's side of the family, Cass estimated that "he was two-eighths Swedish, oneeighth German, [and] one-eighth Norwegian." ${ }^{44}$ Taken altogether, the ethnic composition of the Timberlane generation of which Cass was a member was probably remarkably average and representative. Sinclair Lewis addresses the prominent quandary of the 1940s in the United States, namely the same question that Crevecoeur posed over a century earlier, "What then is this New American?" Lewis answers the question, predictably, through the voice of a young Finnish Minnesotan, the radical Eino Roskinen. One young man in the group of World War II radicals reports: "But our star is Eino. He has Theories. He says that the new America isn't made up of British stock and Irish and Scotch, but of the Italians and Poles and Icelanders and Finns and Hungarians and Slovaks. People like you [meaning the ethnicity of Cass Timberlane described above] and me are the Red Indians of the country. We'll either pass out entirely or get put on reservations, where we can do our Yankee tribal dances and wear our native evening clothes undisturbed." ${ }^{35}$ The "Yankee" reference is a rhetorical reminder for the reader of the Puritan origins of New England. The only caveat Sinclair Lewis leaves for the reader, unbeknownst to the characters in the novel, is the mixed, "mongrel" heritage and bloodline that the protagonist Cass Timberlane carries. The novel is a poignant reminder that Americans of all kinds carry much mixed heritage or blood. Lewis's story suggests to Americans a half-century later that there has always 
been an "original settler" and there have always been immigrants. At the beginning of the Twenty-First Century, only the names have changed. The story of Cass Timberlane is a cautionary narrative containing an embedded warning of the consequences of defying conformity in a contemporary America that proclaimed a "somewhat open" society. ${ }^{36}$

Overall, even at this early and relatively quiet period of immigration, Milton Gordon demonstrated that American society was in no way assimilated to the degree that was widely assumed in the country's popular culture. ${ }^{37}$ During the period of "consensus" of the 1950s, the radical Sixties, and the more passive 1970s, the assessments of a relatively positive assimilation reported in popular culture were believed to reflect an on-going and gradual process of "Americanization." One interesting reflection of this relative pause in the approach of gradualism in the area of assimilation is the booklength report by John Dos Passos in 1944 entitled The State of the Nation. In the beginning of the book, Dos Passos, who had already completed his important national assessment in the U.S.A. Trilogy, contended that "I know that our system has never been perfect and that all sorts of injustices have flourished under it, but I don't think you'll deny that during the hundred and sixty eight years of the existence of the United States the ordinary run of men here have had a better chance to develop and to live their lives as they wanted to than any other period we know about anywhere else in the world." Dos Passos answered, in advance, some of the concerns Nathan Glazer posed. Dos Passos announced for his country: "During that time our liberties have weathered storms. We are now in the midst of the greatest of them [World War II]...The test finds us far from ready to meet it...Still, I believe we are going to meet it." Dos Passos offers his reason for American resolve: "The people of this country have a common language and have developed a common aptitude for the use of machinery...What holds us together as a nation is our system of liberties...To survive in the coming world at all we shall have to learn how to continue to be a nation of free men." ${ }^{38}$

Clearly, over fifty years ago, John Dos Passos addressed the central concern that contemporary Americans feel during this period of vast demographic and political change. As I noted above, the more useful metaphor for the mosaic of American society today is much like the textile of many colors, or in material folk culture, a traditional knotted rug or the folkloric "rag rug", a rug comprised of many different fabrics. As the society has become ever more complicated, with more colors and fabrics to incorporate into the rug, keeping the rug whole has required both new vision and renewed effort. California is a special case to the United States and current state-level statistics reveal some trends that will be reflected throughout the nation in future years. California is the natural port of entry for many of the emigrants, taking in $28 \%$ of all the legal foreign immigrants nationwide as well as one-third of the refugees and half of the amnesty applicants. What is even more interesting for our question of Americanization is that California is close to becoming the first state in which everyone will be a minority. Between the years 2000 and 2020, Anglos will fall below $50 \%$ while other groups, notably Latinos, will increase with the result being that all ethnic groups will be less that a majority. Even more interesting is the fact that this demographic change is reflected markedly in the percentages of high school graduates where the classes of 2000 and 2008 already illustrate the dramatic shift to a larger number of Latino graduates than Anglo graduates. Finally, if we examine the map of California as a whole, we can see that the demographic transformation demonstrates a complete alteration in the mosaic of minorities throughout the state. This fundamental 
transformation will have a strong impact on public policy, local governance, and ethnic representation..$^{39}$

Throughout the past century of United States history, a dominant theme and concern of American citizens has been the role of identity and assimilation, "the melting pot" and "dual consciousness" in transforming a society comprised of immigrants into what continues to be "The Great Experiment." The fluctuation of American popularity notwithstanding, immigrants persist in arriving to the shores of the United States in greater numbers than at any time in history. An examination of the critical numbers of immigrants from the end of the nineteenth century to the beginning of the TwentyFirst Century, from U.S. Census Bureau data and current information from the New Immigrant Survey [NIS], demonstrate the depth of the circumstance that has seemingly caused the anxiety over immigration within the American population. The cultural information we glean from national and regional events that celebrate our varied ethnic traditions, such as the Festival of American Folklife sponsored by the Smithsonian and the National Folk Festival sponsored by the National Council for the Traditional Arts, as well as multicultural events that emerge in regional celebrations throughout the nation indicate that, as a country, the United States may be adjusting to the demographic changes.

It is a commonplace assumption that, during the period from the 1990s to the present, the idea of multiculturalism emerged as a prevalent positive postulate for social welfare. In the current culture of the United States, people celebrate racial and cultural difference. In this climate, national origins and "mother tongues" are no longer aspects of personal character to be shunned, but rather celebrated. At the end of this discussion, it is apparent that the demographic scenario leaves a bifurcated circumstance. It is at once a problem in the American past and an opportunity for the future. Separate ethnically identified groups including the Hmong, Somali, Bosnians, Latin Americans, East Europeans and other immigrants and refugees have, if not assimilated, found a place in American society without losing their ethnicity and ethnic identity. If we compare the turn of the Nineteenth Century and the turn of the Twentieth Century (see Figure 2), though the number of immigrants and the growth rate of the immigrant population are now much higher than in the past, the foreignborn percentage of the population was still higher between 1900 and the mid-1920s. After World War I and the subsequent immigration restriction laws in the 1920s, the level of immigration to the United States fell considerably. ${ }^{40}$ However, the significant fact is that the current $12.1 \%$ of the population that is foreign-born is higher than at any time in nearly one-hundred years, since the 1920 Census. ${ }^{41}$ According to the 2005 Census data, the entry states of California, New York, Texas, and Florida contain far and away the largest numbers of immigrants. While the ability to assimilate and incorporate immigrants is dependent on a vast array of factors, the New Immigrant Survey of 2003 illustrates that among emigrants aged 25-64 years at the time of their lawful permanent residence, $41 \%$ of spouses of U.S. citizens and $38 \%$ of the employment principals own their own home..$^{42}$ Home ownership is a positive indicator of acculturation into the emigrant's new society. It is significant to note that the individuals and their families mentioned above, the spouses and the principals, owned their own homes, on average, approximately four months after attaining lawful permanent residence. ${ }^{43}$

Peter Morrison also reports on the phenomenon of home ownership. Among new home buyers, he notes, the most common family names for those who are realizing their 
"American dream," as Dos Passos might have put it, are the typical European names Smith and Johnson with the Spanish name Garcia in seventh place. However, significantly, among first time home buyers in Los Angeles, California, Garcia is the most common name followed by Hernandez and Martinez with Johnson in seventh place. ${ }^{44}$ This remarkable new trend in familial names is a reflection of what is beginning to take place throughout American society. The question of a population shift is not simply related to the overall data on immigration but also the shift is detected in the numbers of children and family size of ethnic groups. On May 1, 2008, the Wall street Journal, reported a: "Surge in U.S. Hispanic Population Driven by Birth, not Immigration." Authors Conor Dougherty and Miriam Jordan cite new Census data reporting that in 2008, Hispanics comprise $15 \%$ of the U.S. population, an increase from $12.6 \%$ in 2000. This figure represents an increase of ten million people from 35.7 million in 2000 to 45.5 million in 2008. The article notes that between 2006 and $2007,62 \%$ of the increase in Hispanic population came from births rather than immigration and that the Hispanic population is now moving to areas in the Southeast and Midwest, outside the normal Hispanic population centers. According to the U.S. Census figures of 2008, 67\% of Americans are non-Hispanic white and 12\% are non-Hispanic Black. From 2000 to 2007, Hispanic birth rates were far higher than either non-Hispanic whites or African Americans. The totals were: 8.4 Hispanic births for each 1 death, 2.4 African American births per 1 death, and 1.6 non-Hispanic white births for each 1 death. Finally, between 2000 and 2007, according to the new Census data, 16 states saw a decline in the white population and whites accounted for a majority of population growth in only 11 states. The figures from the most recent Census indicate a fundamental change in the American demographic picture at the dawn of the Twenty-First Century.

Implicit in this investigation is the attempt to understand how people respond to life within a vast multicultural multi-ethnic society-one in which it is incumbent upon those citizens who are active in the social polity to play an integrative role. The society of the United States has become ever more complex and the question of the "myth of Americanization" has become very much more complicated as people begin to understand themselves in fundamental terms even as they begin to comprehend the increasingly complex nature of American society. The traditional questions that applied to American society in the 1960 s are still the most pertinent avenues for understanding the role of the individual vis-à-vis the society at large: the uncertain sense of personal identity, the quickening pace of social change, and the standardization of experience. The only difference in the beginning of the Twenty-First Century is that the sequence of the questions for contemporary American society is somewhat reversed from what it was forty or even thirty years ago. The question of the standardization of experience was seen, in 1960, to refer to the idea that all Americans would somehow arrive at approximately the same spot on the landscape of social change; whether rich or poor, standardization was seen as approximately the same circumstance within which all Americans found themselves. Today, the central questions seem more properly to be the quickness of social change on the American landscape and the uncertain sense of one's personal identity. Americans of all "stripes and colors" today wear their personal identity in overt ways, whether as a headscarf, a tattoo, a religious mark on the skin, or, simply, a traditional coat and tie. At the core of the question of the success of the society is whether or not these overt attempts at selfidentification are recognized with tolerance and acceptability, whether these differences are encouraged and embraced by the citizens of the society. 
In 1903, two literary events occurred that, taken together, articulate the tension in the "myth of Americanization." First, Henry James published The Ambassadors that initially appeared in twelve serial parts in the North American Review. The novel recounts the story of a man who, in searching for another, finds himself. James outlines a phenomenon of the American in European culture who is at once beset with what he calls, on the second page of the novel, "a double consciousness," being two things at once, ${ }^{45}$ a thematic string that follows James throughout his career, ending in his own declaration for English citizenship later in life. At the same time, in 1903, W.E.B. Du Bois published his monumental collection of essays, The Souls of Black Folk, in which he writes that an African American is torn between the sometimes warring allegiances and selfidentifications of being black and being American. Du Bois also refers to the tension the "double consciousness" as the presence of two sometimes separate, sometimes conflicting, cultural identities in an individual. Du Bois argues that the "two-ness" of being "an American and a Negro" is a struggle between "two warring ideals in one black body, whose dogged strength alone kept it from being torn asunder." ${ }^{46}$ Ironically, both writers articulate this position in the same year, perhaps both borrowing the idea from Henry's brother William James who was experimenting with the concept in his own research. James and Du Bois posit the question, to wit, is it inevitable that those who are not part of the primary host society, fall victim to a "double consciousness." One might argue that American society has always celebrated, to one degree or another, elements of "double consciousness" through ethnic folkways, "mother tongues," and forms of American speech that differ from those of a common American dialect. Folk Schools and language camps for Scandinavians were as common at the turn of the last century as Saturday schools are today for Arabic speaking and Asian speaking emigrants of today.

Deeply embedded in the national consciousness and the "myth of Americanization" is the notion of the Du Boisian "two-ness," a double consciousness that offers a definition of the contemporary anxiety of being an immigrant in a host society imbued with ambivalence about the phenomenon of immigration itself. Clearly, the United States is at a crossroads, one that may not be recognized-or ignored-by those immigrants who continue to become part of American society. However, it is obvious that the current debates in the United States regarding what it means to be "Americanized" reflect the tension about identity in the country. What kind of people we might be, when we are so diverse, Glazer's question, has been answered in a variety of ways. Ali Behdad, in a brilliant book entitled A Forgetful Nation, states that "The rhetoric of the immigrant and the foreigner as a threat to democracy and freedom suspended the myth of America as a nation of immigrants until further notice. ${ }^{"}{ }^{77}$ It is true that the folklore about emigrants was that the immigrant helped to engender democracy and freedom by coming to America where ideas and actions were constitutionally protected. And, though Behdad is correct, emigrants are often young people of an age that will not be hampered by the current political debate. The Census data from 2008 indicates that the "American" who has emerged is a being unlike anything Crevecoeur or Tocqueville might have imagined. The creation of the idea of America, and hence Americanization, has many sources-Crevecoeur, Jefferson, Walt Whitman, Henry James, Du Bois -and many roots to be examined, as Ali Behdad did, but like many articles of faith and popular culture, the story of "Americanization" has elided into a complex reality of the population shift today. That reality will evolve into a new picture and story for 
"Americanization" and it will be far different from the society that the emigrants of 1890,1900 , or 1910 might have imagined.

I conclude by remembering my university students, many of whom experience this strong conflict and tension of "two-ness," a double consciousness in their own identity. During the past year I have told students about my research into the myth of Americanization. They are, of course, duly interested, but one particular afternoon a group of students whose families are from India, young men, stayed after class to tell me about their feelings When they told me about a phenomenon called "ABCD," I asked what that meant and they replied "American-Born Confused Desi." "What is Desi?" I asked. Desi is identity, American-born, confused identity, they told me. What I did not realize at that moment was that two of the students were born in the United States and one in India, but they shared the same identity and essentially the same confusion. I was told in late 2008 by a female pharmacist from India that Indians distinguish between early immigrants and those who arrive more recently by referring to them as "FOB," or "Fresh Off the Boat," a more pejorative characterization. ${ }^{48}$ The Indian American pharmacist said she did not like the "FOB" characterization and was sensitive to the negative connotation of the phrase. Two young Ohio-born women students from Indian families told me that their parents cautioned them not to marry a "BMW." What is that, I asked. I knew "BMW" was an acronym for a car. They said together, laughing, "Our parents mean-Black, Muslim, White-don't marry outside Indian." I am reminded of my Iranian-American student whose girlfriend is an Indian American, born in the United States, educated in the suburbs, and whose parents expect she will become a high-achieving, successful American. The world will be changing for her parents as well. The same phenomenon exists in Europe as well. In Ireland, young people call the confusion of identity, "IBC," Irish-Born Children." The "Myth of Americanization" is not now, nor has it ever been, a myth. It is, rather, a long mystery, a very long puzzle, of identity. The numbers and data from the Census and the New Immigrant Survey compel us to begin to understand more deeply the meaning of assimilation and acculturation. The overwhelming numbers of immigrants notwithstanding, the mystery of identity will continue to be more than data. Understanding the puzzle of identity will depend on an examination of deep cultural references and evidence that continue to evolve in everyday life in the United States, redefining our understanding of "E Pluribus Unum" or "E Pluribus Plura."

\section{NOTES}

1. Walt Whitman, Leaves of Grass VI

2. For a historiographic review of the discipline of American Studies during the early years, see John F. Moe, "They Sang to My Eye: A Humanistic Approach to the Study of Material Artifacts," The International Journal of Social Education, Vol. 1, No. 1 (Spring 1986): 37-54.

3. Stephen Crane, “The Blue Hotel," Collier's Weekly, V.22 (November 26, 1898), p.14.

4. Steven A. Camarota, "Immigrants at Mid-Decade: A Snapshot of America's Foreign-Born Population in 2005." Center for Immigration Studies, Washington, D.C. December, 2005. 
5. Steven A. Camarota, "Immigrants at Mid-Decade: A Snapshot of America's Foreign-Born Population in 2005," p.5.

6. Stiftelsen Norsk Utvandrermuseum og Forskningssenter (The Norwegian Emigrant Museum and Research Center Foundation), Ottestad, Norway. The folklore fieldwork research on "American Days" was conducted by the author in communities on the west coast of Norway from Bergen to Stavanger.

7. Steven A. Camarota, "Immigrants in the United States, 2007: A Profile of America's ForeignBorn Population." Center for Immigration Studies Backgrounder, November 2007. Figures used with the permission of the author and the Center for Immigration Studies, Washington, D.C.

8. Camarota, p.1. This number includes both legal and illegal immigrants.

9. See my entry "Estonian Communities," in Simon J. Bronner, ed. Encyclopedia of American Folklife, Vol. 1, pp. 338-341.

10. I remember one Estonian family from Chicago whose children, classmates of mine at Grinnell College, were born in the Displaced Persons Camps.

11. His name was Fred Dahl. Each of the 13 children, both boys and girls, in his family carried the middle name Christian, after the Danish King. My middle name, Frederick, comes from my grandfather's first name.

12. Will Weaver, Gravestone Made of Wheat. The title story, one of this collection of stories, was made into a film in 2007 entitled "Sweetland." After the war, many Germans went abroad in Europe to find employment. The woman in Weaver's story comes to America as the result of an "arranged" marriage to wed a Norwegian from the village where she was working in Norway.

13. Harvard University Press, 1980, p.33.

14. Nathan Glazer, "Is There an American People?" What, Then, Is the American, This New Man? Washington, D.C.: Center for Immigration Studies, July, 1998, p.7.

15. An analogue to this question would be a personal encounter when a Norwegian university colleague said to me, while discussing recent Oslo immigration, “Don't you have to be white to be Norwegian?"

16. Peter A. Morrison, “A Demographic Perspective on Our Nation's Future," Santa Monica, CA: RAND Corporation, 2001. http://www.rand.org/pubs/documented_briefings/DB320, p.1.

17. Yamashita, Tropic of Orange. Minneapolis, Minnesota: Coffee House Press, 1997.

18. Oscar Handlin, The Uprooted: The Epic Story of the Great Migrations That Made the American People, 1951.

19. Out of Our Past: The Forces that Shaped Modern America. 1957 (article), book (1970)

20. Glazer, "Is There an American People?" p.7.

21. Bernard Malamud, The Assistant. New York: Avon Books, 1980 (1957), p.297.

22. Glazer, "Is There an American People?" p.7.

23. John Higham, Strangers in the Land: Patterns of American Nativism, 1860-1925. New Brunswick, NJ, 1955.

24. Milton Gordon, Assimilation in American life: the role of race, religion, and national origins, New York: Oxford University press, 1964.

25. Moe and Bronner, "Estonian Communities," p.339.

26. During the first half of the Twentieth Century, various Norwegian-American organizations and institutions supported Norwegian immigrant transition to a hyphenated American community. Such groups include: Arne Garborg Klub, Den Norske Quartet Klub, Det Norske Nationalforbund, Den Norske Klub, Dovre Klub (politics), Sleipner Athletic Club, Norwegian Fish Club (businessmen's luncheon group), American Norwegian Chamber of Commerce, Norwegian Pioneers Club, Norwegian-American Athletic Association, Norwegian Literary Society, Norwegian People's Academy, Norwegian Players, Norwegian Singers' League, Norske Skiklub, NorwegianAmerican Hospital, Norwegian Old People's Home, and several non-church affiliated institutions. 
27. Odd S. Lovoll, "Norwegians," Encyclopedia of Chicago. http:// encyclopedia.chicagohistory.org/pages/911.html.

28. A total of 181,677 Polish language speakers is reported in "The Polish Community in Metro Chicago: A Community Profile of Strengths and Needs, A Census 2000 Report," published by the Polish American Association June 2004, pp.11,18.

29. http://polishweeklychicago.com/index.html

30. See Moe, "They Sang to My Eye: A Humanistic Approach to the Study of Material Artifacts," The International Journal of Social Education, Vol. 1, No. 1 (Spring 1986): 37-40.

31. http://www.trumanlibrary.org/9981.html

32. Joseph Lash, Eleanor and Franklin. New York: W.W. Norton, 1971. See also James MacGregor Burns, Roosevelt: The Lion and the Fox. A Harvest Book. New York: Harcourt, Brace \& World, Inc., 1956, pp. 266 et. passim. Lash's work is the principal study of Anna Eleanor Roosevelt, one of the outstanding proponents of equal treatment for minorities.

33. The name "Babbitt" quickly became a household term for the role of the American businessman in the 1920s and remained a profound examination of the new urban landscape in the United States.

34. Sinclair Lewis, Cass Timberlane: A Novel of Husbands and Wives. New York: Random House, 1945, p.30.

35. Lewis, Cass Timberlane, pp.44-45.

36. Sinclair Lewis' stories in the 1940 s reveal that American writers had come far regarding emigrants since Stephen Crane penned his naturalistic tale "The Blue Hotel," Collier's Weekly, V. 22 (November 26, 1898), wherein the only name for the emigrant character was simply "Swede." In this story set in frontier Nebraska, where Crane worked for a time as a reporter, the ethnic emigrant, albeit from northern Europe, was suspect as one unable to comprehend the subtleties of American society. Reflections on multiethnicity are not reserved only for the United States. Writer Michael Ondaatje considers the multiethnicity of Canadian society in his novel Skin of a Lion. In discussing early factory labor, Ondaatje illustrates new immigration in Ontario by naming the different nationalities of Canadian emigrants from Ireland, Italy, the Scandinavian and Baltic countries as well as other parts of Europe.

37. Gordon, Assimilation in American Life. Chapters 1 and 2.

38. John Dos Passos, State of the Nation. Boston: Houghton Mifflin Company, 1944, p.2.

39. Morrison, “A Demographic Perspective on Our Nation's Future," pp.39-49.

40. The U.S. Immigration Act of 1924, which superseded the higher cap established in the Immigration Restriction Act of 1921, limited the number of immigrants who could be admitted from any country to $2 \%$ of the number of people from that country who already resided in the United States as recorded in the 1890 Census.

41. Camarota, op. cit., pp. 5-7. See also William H. Frey, "Immigration Goes Nationwide: Recent immigrant dispersal has created national policy interest," University of Michigan and the Brookings Institution, Briefing, U.S. Capitol building, March 24, 2006.

42. Guillermina Jasso, et. al., "The U.S. New Immigrant Survey: Overview and Preliminary Results Based on the New-Immigrant Cohorts of 1996 and 2003." September 2004, Revised March 2005, p. 15.

43. Jasso, p.15.

44. Morrison, “A Demographic Perspective on Our Nation's Future,” pp.47-48.

45. Henry James, The Ambassadors, 1903.

46. W.E. Burghardt Du Bois, The Souls of Black Folk, 1903, pp.56-57.

47. Ali Behdad, A Forgetful Nation: On Immigration and Cultural Identity in the United States. Durham \& London: Duke University Press, 2005, p.171. 
48. Interview with informant, October 20-22, 2008. I also collected the "ABCD" and the "FOB" acronyms from a male student, 19 years old, at The Ohio State University, where there is a large number of Indian and Bangladeshi students.

\section{INDEX}

Keywords: American identity, American literature, Americanization, Assimilation, Double consciousness, Immigration, Multicultural society, Social change, U.S. Census, U.S. New Immigrant Survey

\section{AUTHORS}

JOHN F. MOE

Ohio State University 